This document was prepared in conjunction with work accomplished under Contract No. DE-AC09-96SR18500 with the U. S. Department of Energy.

\title{
DISCLAIMER
}

This report was prepared as an account of work sponsored by an agency of the United States Government. Neither the United States Government nor any agency thereof, nor any of their employees, makes any warranty, express or implied, or assumes any legal liability or responsibility for the accuracy, completeness, or usefulness of any information, apparatus, product or process disclosed, or represents that its use would not infringe privately owned rights. Reference herein to any specific commercial product, process or service by trade name, trademark, manufacturer, or otherwise does not necessarily constitute or imply its endorsement, recommendation, or favoring by the United States Government or any agency thereof. The views and opinions of authors expressed herein do not necessarily state or reflect those of the United States Government or any agency thereof.

This report has been reproduced directly from the best available copy.

Available for sale to the public, in paper, from: U.S. Department of Commerce, National Technical Information Service, 5285 Port Royal Road, Springfield, VA 22161, phone: (800) 553-6847, fax: (703) 605-6900

email: orders@ntis.fedworld.gov

online ordering: http://www.ntis.gov/help/index.asp

Available electronically at http://www.osti.gov/bridge

Available for a processing fee to U.S. Department of Energy and its contractors, in paper, from: U.S. Department of Energy, Office of Scientific and Technical Information, P.O. Box 62, Oak Ridge, TN 37831-0062,

phone: (865)576-8401,

fax: (865)576-5728

email: $\underline{\text { reports@ adonis.osti.gov }}$ 


\section{ASSESSMENT OF GENOTOXIC ACTIVITY OF PETROLEUM HYDROCARBON-BIOREMEDIATED SOIL}

Grażyna Płaza ${ }^{1}$, Grzegorz Nałęcz-Jawecki ${ }^{2}$, Krzysztof Ulfig ${ }^{1}$, Robin L. Brigmon ${ }^{3}$

1 - Institute for Ecology of Industrial Areas, 40-844 Katowice, Kossutha 6 Street, Poland

2 - Department of Environmental Health Sciences, Medical University, Banacha 1 Street, 02-097 Warszawa, Poland

3 - Savannah River National Laboratory, Aiken, South Carolina, 29808, USA 


\begin{abstract}
The relationship between toxicity and soil contamination must be understood to develop reliable indicators of environmental restoration for bioremediation. Two bacterial rapid bioassays: SOS chromotest and umu-test with and without metabolic activation (S-9 mixture) were used to evaluate genotoxicity of petroleum hydrocarbon-contaminated soil following bioremediation treatment. The soil was taken from an engineered biopile at the Czor Polish oil refinery. The bioremediation process in the biopile lasted 4 years, and the toxicity measurements were done after this treatment. Carcinogens detected in the soil, polyaromatic hydrocarbons (PAHs), were reduced to low concentrations ( $2 \mathrm{mg} / \mathrm{kg}$ dry $\mathrm{wt}$ ) by the bioremediation process. Genotoxicity was not observed for soils tested with and without metabolic activation by a liver homogenate (S-9 mixture). However, umu-test was more sensitive than SOS-chromotest in the analysis of petroleum hydrocarbon-bioremediated soil. Analytical results of soil used in the bioassays confirmed that the bioremediation process reduced $81 \%$ of the petroleum hydrocarbons including PAHs. We conclude that the combined test systems employed in this study are useful tools for the genotoxic examination of remediated petroleum hydrocarbon-contaminated soil.
\end{abstract}

Keywords: genotoxicity, petroleum hydrocarbons, bioremediation, biopile, PAHs 


\section{Introduction}

The success of bioremediation is determined by the metabolic potential of microorganisms to detoxify/utilize organic contaminants or mineralize them to $\mathrm{CO}_{2}, \mathrm{H}_{2} \mathrm{O}$ and biomass. The process is highly dependent on biodegradability and bioavailability of contaminants as well as environmental parameters including $\mathrm{pH}$, temperature, and nutrient availability (ref). Bioremediation is an attractive, environmentally friendly, and relatively cost-effective alternative to conventional physicochemical soil and water treatment techniques (Bouwer et al., 1994; Barthe, 1986). There are a variety of in situ and ex situ bioremediation approaches, including biopiling, bioreactors, bioventing, biosparging and landfarming that can be applied to optimize biodegradation (Brigmon et al. 2002, Hazen, 1997; Bouwer et al., 1994).

Considering different existing bioremediation strategies and characteristics of the lagoon materials at the Czechowice-Dziedzice refinery, the ex situ/on site bioremediation in biopile was selected to clean-up soil heavily contaminated with petroleum waste (Plaza et al, 2003). As a result of bioremediation no secondary waste stream is created, contaminants are safely treated in situ therefore minimizing handling and associated health hazards, and the reuse of the previously contaminated site without restriction is possible.

A number of rapid test systems to detect environmental carcinogens have been devised for soil and water analyses. The umu-test and SOS chromotest have been widely employed for soil testing with successful results (Reifferscheid et al. 1991). The SOS chromotest described by Quilardet et al. (1982) uses one of the SOS (define) genes, sfi A focused to lac $Z$ on the chromosome of $E$. coli, and overcomes the drawback in the Ames test. The umu-test is based on the use of genetically engineered bacteria, Salmonella typhimurium TA 1535 pSK 1002. The umu-test has been standardized and validated by German DIN (DIN 38415 T3) and on the international level by ISO (ISO/DIS 13829, 2000). In this project genotoxicity assessment of remediated hydrocarbon-contaminated soil was performed with the SOS-chromotest and umu-tests.

\section{Materials and methods}

\subsection{Field description}


More than a century of sulphuric acid-based oil refining process by the CZOR refinery and associated waste disposal has produced an estimated 120,000 tons of acidic, highly weathered, petroleum sludge and wastewater. This waste has been deposited into three open waste lagoons, 3 meters deep and covering 3.8 hectares. One of the waste lagoons $(0.3$ hectare) was chosen for aerobic biopile demonstration (Plaza et al. 2003). The waste from this lagoon was removed, and heavily petroleum contaminated soil was engineered into a biopile for bioremediation. The biopile was constructed with actively and passively aerated sections in 1997 (Plaza et al, 2004). The project focus was on evaluation of novel environmental restoration technologies and research for effective bioremediation of heavily contaminated petroleum waste soils. This was accomplished by comparing bioremediation processes and the contaminant removal rates of both easily biodegradable light petroleum hydrocarbons and more recalcitrant polyaromatic hydrocarbons (PAHs) under active vs. passive aeration. The application efficiently employed cost-effective additives, including mineral NPK fertilizers, the surfactant Rokafenol N8, and employing indigenous microbial consortium for enhanced biodegradation of soil hydrocarbons in the biopile.

The sampling strategy was similar to that applied in a previous project (Altman et al., 1997; IETU, 1999). The total number of soil sampling locations at the biopile was twentythree. Soil was sampled (ca. $1 \mathrm{~kg}$ ) from shallow (ca. 30-40 cm) and deep (ca. 80-100 cm) layers. The soil sampling locations in the biopile are presented in Figure 1.

\subsection{Characterization of soil samples}

Each soil sample was examined for the following physicochemical parameters: TPH (total petroleum hydrocarbons), non-polar aliphatic hydrocarbons; TPOC - (total petroleum organic carbon); POLAR - (polar aliphatic petroleum compounds); total PAHs - (polycyclic aromatic hydrocarbons), 16 PAHs according to EPA (EPA Method 3620, 1992; EPA Method 8440, 1995); $\mathrm{pH}$ in $\mathrm{H}_{2} \mathrm{O}$; $\mathrm{pH}$ in $1 \mathrm{M} \mathrm{KCl}$; conductivity; $\mathrm{N}-\mathrm{NH}_{4}, \mathrm{~N}-\mathrm{NO}_{2}, \mathrm{~N}_{-} \mathrm{NO}_{3}, \mathrm{PO}_{4}, \mathrm{Ca}, \mathrm{Mg}$, $\mathrm{C}_{\text {TOT }}, \mathrm{N}_{\text {TOT }}, \mathrm{P}_{\text {TOт }}, \mathrm{P}_{2} \mathrm{O}_{5}, \mathrm{~K}_{2} \mathrm{O}$, and metals were measured according to ISO standards. Soil microbial activity was measured by the dehydrogenase activity according to Alef and 
Nannipieri (1996). This method is based on the use of TTC (triphenyltetrazolium chloride)) as an artificial electron acceptor.

\subsection{Extraction of soil samples}

All soil samples from each location were mixed and split for the two bioassays. The remediated soil extraction procedure was performed as described by McDaniel et al. (1993). Five grams of soil was extracted for $16 \mathrm{~h}$ in a Soxhlet extractor with methylene chloride. A rotary evaporator was then used to reduce the extract volume to $5 \mathrm{ml}$. One $\mathrm{ml}$ of DMSO (dimethyl sulfoxide)) was then added and the resultant mixture evaporated under reduced pressure to $1 \mathrm{ml}$. The exchange solvent - DMSO was selected as it is not toxic and genotoxic to the bacteria tested.

\subsection{Genotoxicity bioassays}

The SOS-chromotest with Escherichia coli PQ37 was performed on the soils in $20 \mathrm{ml}$ sterile glass test tubes with and without S9 metabolic activation, according to a modified method described by Quillardet and Hofnung (1985). Umu test with Salmonella typhimurium TA1535/pSK1002 was carried out on the soils according to the method of Oda et al. (1985). The incubation mixture consisted of $5,10 \mu \mathrm{l}$ (SOS) or 20, $30 \mu 1$ (umu) extracts, log-phase bacterial culture and S9 mix containing 4\% of S9. These bioassay results can be influenced by sample color so two different procedures were applied to eliminate this bias. In case of the umu test the bacterial suspension was diluted 10-fold with the fresh medium after $2 \mathrm{~h}$ of exposure, followed by an additional incubation period of $2 \mathrm{~h}$. In the SOS-chromotest the bacterial suspension was centrifuged and rinsed twice with fresh medium. All soil samples were tested in triplicate.

\section{Results}

Results of soil physical-chemical analyses of the biopile soil used in these bioassays are presented in Table 1 . The soil characterization results demonstrate contaminant concentrations necessary to determine test endpoint differences. The soil $\mathrm{pH}$ was $6.13-7.18$ 
with a mean of 6.6. The metal concentrations varied within natural concentration ranges determined for Polish soils. The mean TPH, TPOC and PAH concentrations were $6.05 \mathrm{~g} / \mathrm{kg}$ d.w., $7.38 \mathrm{~g} / \mathrm{kg}$ d.w., and $2.21 \mathrm{mg} / \mathrm{kg}$ d.w., respectively. The hydrocarbon concentrations decreased $81 \%$ during bioremediation in this biopile. By the end of the $20^{\text {th }}$ month of bioremediation, the TPH and PAH concentrations were reduced below the Polish risk guidelines (PIOS, 1994 not in ref list). A restored green area having lush vegetation including grass and trees now covers the biopile surface. After 48 months the active bioremediation process was terminated and monitored natural attenuation (MNA) was selected as the followup bioremediation strategy for this site. Decreases of petroleum hydrocarbon concentrations during the bioremediation treatment are presented in Table 2. It is calculated that 120 tons of petroleum hydrocarbons were removed during this period (IETU, 1999). The significant decrease of petroleum hydrocarbons and corresponding high dehydrogenase activity were noted during the first year of the bioremediation process (Plaza et al 2003a).

The initial air injection into the biopile after construction stimulated significant reductions of contaminants $(>50 \%)$. This reduction was likely due to increased bioavailability of the contamiants after soil mixing and addition of wood chips to allow aeration. While some of this initial reduction may have been due to volatilization, the increase in biopile biomass was correlated with soil organic contaminant reduction demonstrating biodegradation (Plaza et al. 2003). The addition of fertilizers (NPK) and surfactant - Rokafenol N8 together with air and leachate recirculation accelerated the bioremediation process. A biopile is a relatively simple and low maintenance operation. The technology provides operating conditions that minimize fugitive air emissions and maximize biodegradation rates.

The use of bioassays combined with chemical analyses at this site has yielded reliable results for risk analyses (Plaza et al, 2004a). These results demonstrate that active bioremediation can reduce the toxicity of contaminated soils using different genotoxicity tests. Bioremediation improves the soil quality by safely reducing petroleum hydrocarbons as measured by site physico-chemical parameters and specific microbiological activity (Plaza et al. 2004b).

The results of genotoxicity tests with and without metabolic activation are presented in Table 3. The sample is considered genotoxic if $\beta$-galactosidase induction coefficient is higher than 1.5. Induction factor (IF) is defined as the ratio of specific activity of $\beta$-galactosidase at a given sample concentration to specific $\beta$-galactosidase activity. The SOS-chromotest IF 
coefficient for the tested soils was 1.09 with values ranging between $0.86-1.63$. Only one IF coefficient was $>1.5$ out of the 23 samples, probably due to soil toxicity. Decreased phosphatase activity was also observed in this particular soil sample. Similar results were obtained in the bioassay with metabolic activation (S-9 mixture). Mean value of IF was 1.18 with ranged values between $1.00-1.20$. Umu-test responses to the soil samples were generally similar to the SOS-chromotest. The values of IR (Define) coefficients for all test samples were low, but in tests with metabolic activation the values of IR were slightly higher. Mean values of IR coefficient were 1.02 and 0.86 with and without metabolic activation, respectively. The biopile soil was originally contaminated by potentially genotoxic compounds such as benzo(a)pyrene, dibenzo(a,h)anthracene, benzo(b)fluoranthene and benzo(k)fluoranthene). Bioassay results utilizing these PAHs, although known to be genotoxic, can vary with test organisms depending on the bioavailability (Alexander and Alexander, 2000). However PAH concentration was reduced by the time of this testing and did not cause apparent genotoxic effects here. The umu-test is considered more sensitive than SOS-chromotest. For the positive controls (2-aminoanthracene with S9 activation) the umutest was 5-fold more sensitive than the SOS-chromotest.

\section{Discussion}

A biopile is a relatively simple and low maintenance operation. The technology provides operating conditions that minimize fugitive air emissions and maximize biodegradation rates. Bioremediation improves the soil quality by safely reducing petroleum hydrocarbons as measured by site physico-chemical parameters and specific microbiological activity (Płaza et al. 2003). The use of bioassays at this site combined with chemical analyses has proven to yield reliable results for genotoxic risk analyses. These results confirm the effect of active bioremediation upon reducing the genotoxicity of contaminated soils in SOS chromotest and umu-test.

This study demonstrated that genotoxic risk from treated biopile soil was not observed. The results indicated some differences between these two bioassays. Both tests were more sensitive after enzymatic activation of the soil samples. This demonstrates that the soil contaminants causing genotoxic effects, petroleum hydrocarbons and PAHs, were 
transformed by enzymatic activity. Soil sample processing, for example extraction technique, is critical to contaminant bioavailability and measurements of genotoxicity (Alexander and Alexander, 2000). The results obtained from the assays are in accordance with chemical analyses. Based on these results, this bioremediation demonstration has successfully reduced the genotoxicity from the soil contaminants in the biopile.

The combination of two bioassays used here for examination of petroleum hydrocarbon-contaminated soil genotoxic activity after bioremediation was comparable to data from chemical testing. The findings that contaminants were significantly reduced matched the genotoxicity findings. The bioassays covered a wide range of mutagenic reference substances and complement each other (Quillardet and Hofnung, 1993). The results demonstrated that the umu and SOS test systems with and without metabolic activation were suitable for evaluation of soil genotoxicity. All the assays used are potentially useful in the detection of genotoxicity. However, each test showed different sensitivities to remediated soil. Thus, we suggest, as other authors have done, a battery approach for biological evaluation of genotoxicity (DECHEMA, 1995; Weisburger, 1999; Ehrlichmann et al., 2000; Bundy, 2000) or toxicity (Baun et al., 2000) of environmental samples. There is a need to develop environmentally acceptable endpoints for soil quality and an integrated approach to estimate ecological risk. The use of biological endpoints to evaluate contaminated sites remediated to regulatory cleanup levels should be incorporated into ecological risk assessment. These and other soil genotoxicity bioassays could be useful tools for development of predictive models for risk-based corrective actions (Citterio et al., 2002). These endpoints could be included in regulatory guidelines for assessing remedial effectiveness for both engineered and MNA environmental restoration programs. 


\section{Acknowledgements}

The authors would like to express their gratitude to the U.S. Department of Energy's JCCES Program, the Florida State University, Westinghouse Savannah River Technology Center, Czechowice-Dziedzice oil refinery, and the Polish Committee for Scientific Research (project no. 4 TO9D03422) for their technical and financial support. This paper was prepared in connection with work done under Contract No. DE-AC09-96SR18500 with the U. S. Department of Energy.

\section{References}

1. Alef K. (1996) Dehydrogenase activity. In: Methods in Applied Soil Microbiology and Biochemistry. Eds. K Alef \& P. Nannipieri. Academic Press, Harcourt Brace \& Company, Publishers, London-Toronto.

2. Alexander R.R., Alexander, M. (2000) Bioavailability of genotoxic compounds in soils. Environ. Sci. Technol. 34, 1589-1593.

3. Barthe R. (1986) Biotechnology of petroleum pollutant biodegradation. Microbiology Ecology, 12, 155-172.

4. Baun A., Jensen S.D., Bjerg P.L., Christensen T.H., Nyholm N. (2000) Toxicity of Organic Chemical Pollution in Groundwater Downgradient of a Landfill (Grindsted, Denmark). Environ. Sci. Technol. 34, 1647-1652.

5. Bonisławska, A., Demkowicz-Dobrzański, K., Nałęcz-Jawecki, G., Mankiewicz, J., Tarczyńska, M., Sawicki, J. (2003) SOS-Chromotest genotoxicity and toxicity of cyanobacterial extracts from reservoir surface water. Fresenius Environ. Bull. 12, 1144-1151.

6. Bouwer E., Durant N., Wilson L., Zhang W., Cunningham A. (1994) Degradation of xenobiotic compounds in situ: capabilities and limits, FEMS Microbiol. Rev. 15, $307-$ 317.

7. Brigmon R.L., Camper D., Stutzenberger F. (2002) Bioremediation of compounds hazardous to health and the environment - an overview. In Biotransformations: Bioremediation Technology for Health and Environmental Protection, edited by V. P. Singh. P. 1-28. The Netherlands: Elsevier Science Publishers.

8. Citterio, S., Aina, R., Labra M., Ghiani A., Fumaglli P., Sgorbati S., Santagostino A. (2002) Soil genotoxicity assessment: a new strategy based on biomolecular tools and plant bioindicators. Environ. Sci. Technol. 36, 2748-2753. 
9. DECHEMA, (1995) Bioassays for soils. 4th Report of the Interdisciplinary DECHEMA Committee "Environmental Biotechnology- Soil.

10. DIN 38415 T3, (1995) Deutsche Einheitsverfahren zur Wasser-, abwasser- und Schlammuntersuchung. Suborganismische Terstverfahren (Gruppe T). Bestimmung des erbgutveraendernden Potentials von Wasser und Abwasser mit dem umu-Test38412 T3. VCH Verlagsgesellschaft mbh. Weinheim, Germany.

11. Dorn P.B., Vipond T.E., Salanitro J.P., Wisniewski H.L. (1998) Assessment of the acute toxicity of crude oils in soils using earthworms, Microtox ${ }^{\circledR}$, and plants. Chemosphere 37, 845-860.

12. Ehrlichman H., Dott W., Eisentraeger A. (2000) Assessment of the water-extractable genotoxic potential of soil samples from contaminated sites. Ecotoxicol. Environ. Safety 46, 73-80.

13. Greene J.C., Bartels C.L., Warren-Hicks W.J., Parkhurst B.R., Linder G.L., Peterson S.A., Miller W.E. (1988): Protocols for short term toxicity screening of hazardous waste sites. EPA/600/3-88/029. U.S.EPA, Corvallis, OR.

14. Hazen T.C. (1997) "Bioremediation” In: Microbiology of the Terrestrial Subsurface. P. Amy \& D. Haldeman (eds.), pp. 247-266, CRC Press, Boca Raton, FL, 1997.

15. http://www.epa.gov/SW-846/pdfs/3630c.pdf

16. International Standardization Organization (ISO) 13829, (2000) Water quality Determination of the genotoxicity of water and wastewater using umu-test.

17. MacNaughton S.J., Stephen J.R., Venosa A.D., Davis G.A., Chang Y-J, White D.C. (1999). Microbial population changes during bioremediation of an experimental oil spill. App. Environ. Microbiol. 65: 3566-3574.

18. McDaniels A.E., Reyes A.L., Wymer L.J., Rankin C.C., Stelma G.N. (1990) Comparison of the Salmonella (Ames) test, umu test, and SOS chromotest for detecting genotoxins. Environ Mol Mutagen 16, 204-215.

19. McDaniels A.E., Reyes A.L., Wymer L.J., Rankin C.C., Stelma G.N. (1993). Genotoxic activity detected in soils from a hazardous waste site by the Ames test and the SOS colorimetric test. Environmental and Molecular Mutagenesis 22, 115-22.

20. Mersch-Sudermann V. (1991) The SOS-chromo-spottest: Evaluation of a short-term test for the determination of genotoxic compounds in contaminated environmental samples. Int J Hyg Environ Med 191, 36-45. 
21. Oda Y., Nakamura S-I., Oki I., Kato T., Shinagawa H. (1985) Evaluation of the new system (umu-test) for the detection of environmental mutagens and carcinogens. Mutation Res. 147, 219-29.

22. Państwowa Inspekcja Ochrony Środowiska, (PIOS), (1994) Wskazówki metodyczne do oceny stopnia zanieczyszczenia gruntów i wód podziemnych produktami ropopochodnymi i innymi substancjami chemicznymi w procesach rekultywacji. Warszawa (in Polish).

23. Plaza, G., K. Ulfig, G. Makina, B. Krezminska, R. L. Brigmon, A. Worstztynowicz. (2003) "Evaluation of bioremediation processes at the oil refinery in CzechowiceDziedzice. Polish” In: Pawlowski, L., Dudzinska, M.R., Pawlowski, A. (Eds.) Environmental Engineering Studies: Polish Research on the Way to the EU. Kluwer Academic, New York. Pp 409-419.

24. Plaza, G., Nalecz-Jawecki G., Ulfig K. Brigmon R.L.. 2004. "Evaluation of Leachate Toxicity to Assess Bioremediation Progress." Fresenius Environ. Bull. 13:532-536.

25. Quillardet P., Hofnung M. (1985). The SOS Chromotest, a colorimetric bacterial assay for genotoxins, procedures. Mutation Res. 147, 65-78.

26. Quillardet P., Hofnung M. (1993) The SOS chromotest: A review. Mutat. Res. 297, 235-279.

27. Reifferscheid G., Heil J., Oda Y., Zahn R.K. (1991) Validation of the SOS/umu tests using test results of 486 chemicals and comparison with the Ames test and carcinogenicity data. Mutat. Res. 369, 129-145.

28. Weisburger, J.H., (1999) Carcinogenicity and mutagenicity testing, then and now. Mutation Res. 437, 105-112. 
Table 1. Physico-chemical characteristics of the biopile soil.

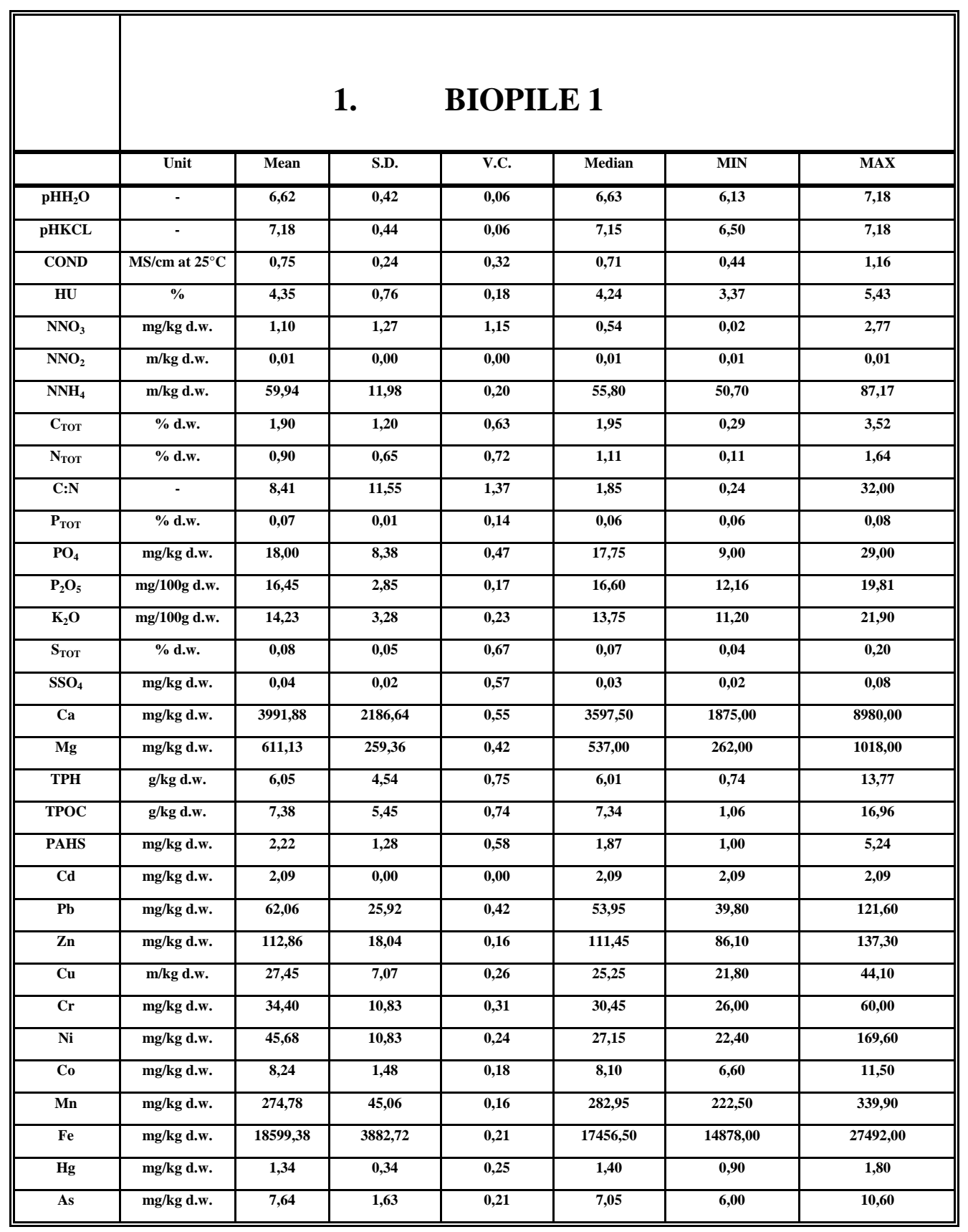

S.D. - standard deviation

V.C. - variation coefficient 
Table 2. Changes in biopile petroleum hydrocarbons concentrations and microbial activity (means for years) during bioremediation.

\begin{tabular}{|c|c|c|c|c|c|}
\hline \multirow{2}{*}{ Years } & TTC & TPH & TPOC & POLAR & PAHs \\
\cline { 2 - 6 } & mg TPF/g d.w. & g/kg d.w. & g/kg d.w. & g/kg d.w. & mg/kg d.w. \\
\hline 1 & 6.05 & 35.25 & 50.06 & 14.81 & 6.97 \\
\hline 2 & 22.46 & 17.04 & 28.03 & 10.99 & 5.21 \\
\hline 3 & 20.07 & 14.17 & 17.03 & 2.15 & 3.44 \\
\hline 4 & 41.57 & 7.93 & 9.65 & 1.93 & 2.44 \\
\hline
\end{tabular}


Table 3. Genotoxicity results of the biopile soil

\begin{tabular}{|l|c|c|c|c|c|c|c||}
\hline & unit & Mean & S.D. & V.C. & Median & MIN & MAX \\
\hline \hline SOS-chromotest & IF & 1,09 & 0,25 & 0,21 & 1,12 & 0,86 & 1,63 \\
\hline $\begin{array}{l}\text { SOS-chromotest with } \\
\text { S-9 activation }\end{array}$ & IF & 1,18 & 0,07 & 0,07 & 1,06 & 1,00 & 1,20 \\
\hline umu-test & IR & 0,86 & 0,07 & 0,09 & 0,89 & 0,74 & 0,93 \\
\hline $\begin{array}{l}\text { umu-test with } \\
\text { S-9 activation }\end{array}$ & IR & 1,02 & 0,07 & 0,07 & 1,00 & 0,93 & 1,16 \\
\hline
\end{tabular}




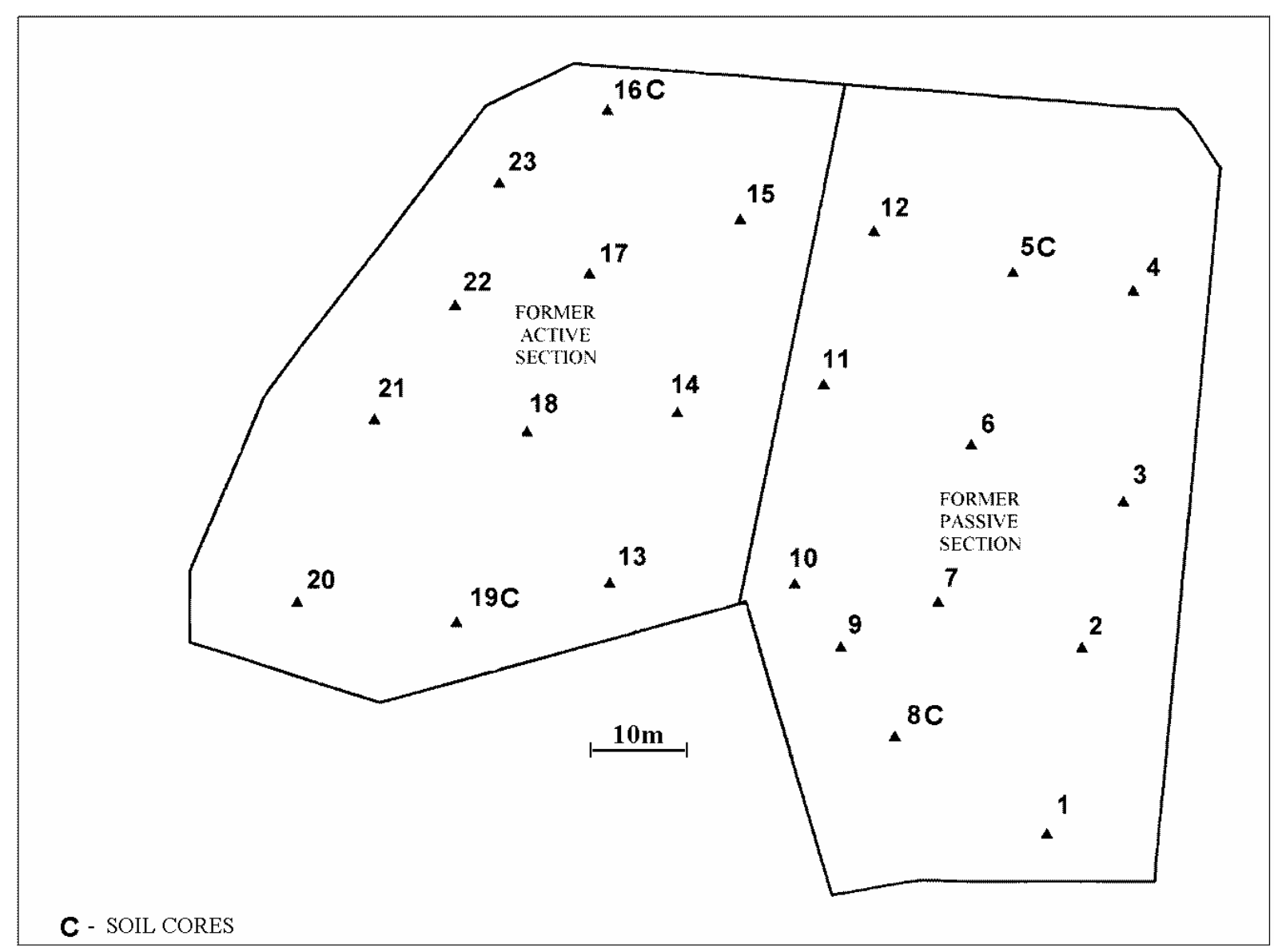

Figure. 1. Biopile sections and soil sampling locations 